\title{
BIOMASSA KANDUNGAN KARBON DAN SERAPAN CO2 PADA TEGAKAN MANGROVE DI KAWASAN KONSERVASI MANGROVE BEDONO, DEMAK
}

\author{
Mangrove Carbon Biomass and Absorption Ability of Carbon Dioxide (CO $\left.\mathrm{C}_{2}\right)$ \\ at Mangrove Conservation Area, Bedono, Demak
}

Teguh Budi Prakoso, Norma Afiati*) dan Djoko Suprapto

Program Studi Manajemen Sumberdaya Perairan, Departemen Sumberdaya Akuatik

Fakultas Perikanan dan Ilmu Kelautan, Universitas Diponegoro

J1. Prof. Soedarto, SH, Tembalang, Semarang, Jawa Tengah -50275 , Telp/Fax. +62247474698

Email : teguhbp98@gmail.com

\begin{abstract}
ABSTRAK
Emisi $\mathrm{CO}_{2}$ yang terakumulasi di atmosfer menyebabkan terjadinya perubahan iklim secara global. Untuk mengurangi dampak perubahan iklim, salah satu upaya yang dapat dilakukan saat ini adalah meningkatkan penyerapan karbon dan/atau menurunkan emisi di atmosfer. Ekosistem mangrove memiliki fungsi ekologis sebagai pereduksi karbon melalui proses sekuestrasi (C-sequestration). Tujuan dari penelitian ini untuk menghitung kerapatan, kandungan karbon dan serapan $\mathrm{CO}_{2}$ serta mengetahui hubungan korelasi kerapatan mangrove dengan kandungan karbon pada tegakan mangrove. Penelitian dilakukan dengan metode non-destructive sampling menggunakan persamaan alometrik. Pendekatan persamaan alometrik yang digunakan yaitu model alometrik biomassa pohon untuk jenis atau tipe ekosistem mangrove yang sudah tersedia atau dikembangkan di lokasi lain. Hasil pengukuran menunjukkan kerapatan tegakan mangrove di area tanam tahun 2004, 2007, dan 2010 adalah 1460 individu/ha, 1868 individu/ha, dan 2128 individu/ha. Biomassa pada area tanam tahun 2004 sebesar 206,77 ton/ha (103,39 ton C/ha, dan menyerap 379,09 ton $\mathrm{CO}_{2} /$ ha). Area tanam tahun 2007 memiliki biomassa 293,73 ton/ha (146,86 ton $\mathrm{C} / \mathrm{ha}$, dan menyerap 538,50 ton $\left.\mathrm{CO}_{2} / \mathrm{ha}\right)$, dan area tanam tahun 2010 memiliki biomassa 260,02 ton/ha (130,01 ton $\mathrm{C} /$ ha, dan menyerap 476,67 ton $\mathrm{CO}_{2} / \mathrm{ha}$ ). Berdasarkan hasil penelitian, kerapatan jenis dan umur tegakan mangrove merupakan faktor yang mempengaruhi besarnya biomassa. Hasil uji regresi-korelasi menunjukkan, perubahan kerapatan mangrove akan berpengaruh secara signifikan pada ekosistem mangrove dalam menyimpan karbon dan menyerap $\mathrm{CO}_{2}$ dari atmosfer.
\end{abstract}

Kata Kunci: Mangrove, biomassa, karbon, kerapatan jenis

\begin{abstract}
Emissions of $\mathrm{CO}_{2}$ that accumulated in the atmosphere causes global climate change. To reduce the impact of climate change, one of the efforts is increased carbon sequestration. The mangrove ecosystem has ecological function as reducing carbon through sequestration process (C-sequestration). Aimed of this research to calculate the density, carbon content and absorption ability $\mathrm{CO}_{2}$ as well as knowing the correlation of mangrove density with carbon sequestration in mangrove. The method used in this research is use non destructive sampling method with allometric equation. The approach allometric equations were used that tree biomass allometric models for the type or types of mangrove ecosystems that are already available or developed in other locations. The measurement results of mangrove density in planting area 2004, 2007 and 2010 were 1,460 individuals/ha, 1868 individuals/ha, and 2128 individuals/ha. Biomass at the planting area in 2004 amounted to 206.77 ton/ha (103.39 ton C/ha, and absorbs 379.09 ton CO $/$ ha). Planting area in 2007 have biomass 293.73 ton / ha (146.86 ton C/ha, and absorbs 538.50 ton $\mathrm{CO}_{2} / \mathrm{ha}$ ), and the planting area in 2010 have biomass 260.02 ton/ha (130.01 ton C/ha, and absorbs 476.67 ton $\mathrm{CO}_{2} / \mathrm{ha}$ ). Based on the research results, the density of mangrove species and age are factors that influence the amount of tree biomass. The results of regression-correlation analysis showed, if mangrove density change significantly, it can influence the mangrove ecosystem in carbon sequestration and absorb $\mathrm{CO}_{2}$ from the atmosphere.
\end{abstract}

Keywords: Mangrove, biomass, carbon, mangrove density

*) Penulis penanggungjawab 


\section{PENDAHULUAN}

Pemanasan global merupakan salah satu isu dunia saat ini, ditandai dengan peristiwa meningkatnya suhu rata-rata permukaan bumi terkait dengan gas-gas rumah kaca (GRK). Salah satu yang menyebabkan meningkatnya jumlah gas rumah kaca adalah emisi $\mathrm{CO}_{2}$ melalui pembakaran lahan, emisi dari kendaraan bermotor dan limbah pabrik (Sedjarawan et al., 2014). Untuk mengurangi dampak perubahan iklim, salah satu upaya yang dapat dilakukan saat ini adalah meningkatkan penyerapan karbon dan/atau menurunkan emisi karbon (Syam'ani et al., 2012).

Luas perairan Indonesia lebih besar daripada luas daratan. Penurunan jumlah hutan mangrove akibat aktivitas manusia ataupun lainnya berdampak terhadap daya serap karbon di bumi. Blue carbon merupakan konsep baru dalam mengurangi emisi $\mathrm{CO}_{2}$. Blue carbon adalah pemanfaatan ekosistem pesisir (mangrove, lamun, etuari dan rawa payau) dalam menyerap $\mathrm{CO}_{2}$ melalui fotosintesis dan menyimpan (sequestration) dalam bentuk biomassa (Donato et al. 2011).

Kerusakan tegakan mangrove juga berarti lepasnya sejumlah besar karbon yang tersimpan sehingga memperburuk pemanasan global serta tren perubahan iklim lainnya (Ramsar Secretariat, 2001 dalam Gilman, 2008). Menurut Maiti dan Chowdhury (2013), mangrove berperan sebagai penyerap karbon dari atmosfir yang efektif dengan jumlah yang lebih tinggi (daripada jenis hutan non-bakau lainnya) yaitu \pm berjumlah 100 ton $\mathrm{CO}_{2}$ per hektar (Ha). Donato et al. (2011) memaparkan bahwa, hutan bakau pesisir dan muara mempertahankan 1.023 Mg karbon per hektar.

Desa Bedono terletak di Kecamatan Sayung, Kabupaten Demak berbatasan langsung dengan laut Jawa. Wilayah Desa Bedono memiliki luas 739 Ha, berupa pemukiman warga, tambak dan kawasan mangrove. Kawasan mangrove desa tersebut memiliki luas $330 \mathrm{Ha}$, dan didominasi oleh jenis mangrove Rhizophora sp. dan Avicennia sp. Hutan mangrove sangat menunjang kebutuhan ekonomi masyarakat sekitar. Oleh karena itu, sumberdaya mangrove banyak yang dieksploitasi, sehingga terjadi kerusakan mangrove yang mempengaruhi fungsi hutan mangrove antara lain sebagai penyerap emisi karbon dari atmosfir (Azizah et al. 2013). Data besarnya kandungan karbon dan serapan $\mathrm{CO}_{2}$ pada mangrove di Indonesia masih sedikit, sehingga diperlukan penelitian mengenai serapan karbon pada tegakan mangrove untuk mengetahui tingkat efektifitas serapan karbon.

Tujuan dari penelitian ini adalah sebagai berikut:

1. Mengetahui kerapatan jenis tegakan mangrove di Kawasan Konservasi Mangrove Desa Bedono, Demak berdasarkan umur tahun tanam 2004, 2007,dan 2010;

2. Mengetahui biomassa, potensi kandungan karbon dan serapan $\mathrm{CO} 2$ berdasarkan umur tahun tanam tegakan mangrove.

3. Mengetahui hubungan korelasi kerapatan mangrove dengan kandungan karbon

\section{MATERI DAN METODE PENELITIAN}

\section{A. Waktu dan Lokasi Penelitian}

Penelitian ini dilaksanakan pada bulan September-Oktober 2016 bertempat di kawasan konservasi mangrove Desa Bedono, Kecamatan Sayung, Demak. Perjalanan menuju lokasi hanya dapat ditempuh menggunakan perahu mesin. Pengambilan data dilakukan pada pagi-siang hari pukul 09.00 - 13.30 saat kondisi laut surut. Data diambil dari 3 stasiun mewakili ekosistem mangrove, yaitu stasiun pertama merupakan area tanam mangrove tahun $2004\left(6^{\circ} 54^{\prime} 41,2^{\prime \prime}\right.$ LS dan $110^{\circ} 29^{\prime} 13,8^{\prime \prime}$ BT), stasiun ke-2 merupakan area tanam mangrove tahun 2007 (6 $6^{0} 54^{\prime} 53,5^{\prime \prime}$ LS dan 110 $29^{\prime} 13,5^{\prime \prime}$ BT) dan stasiun ke-3 merupakan area tanam mangrove tahun 2010 (6054'48,5" LS dan 110²9'52,1" BT).

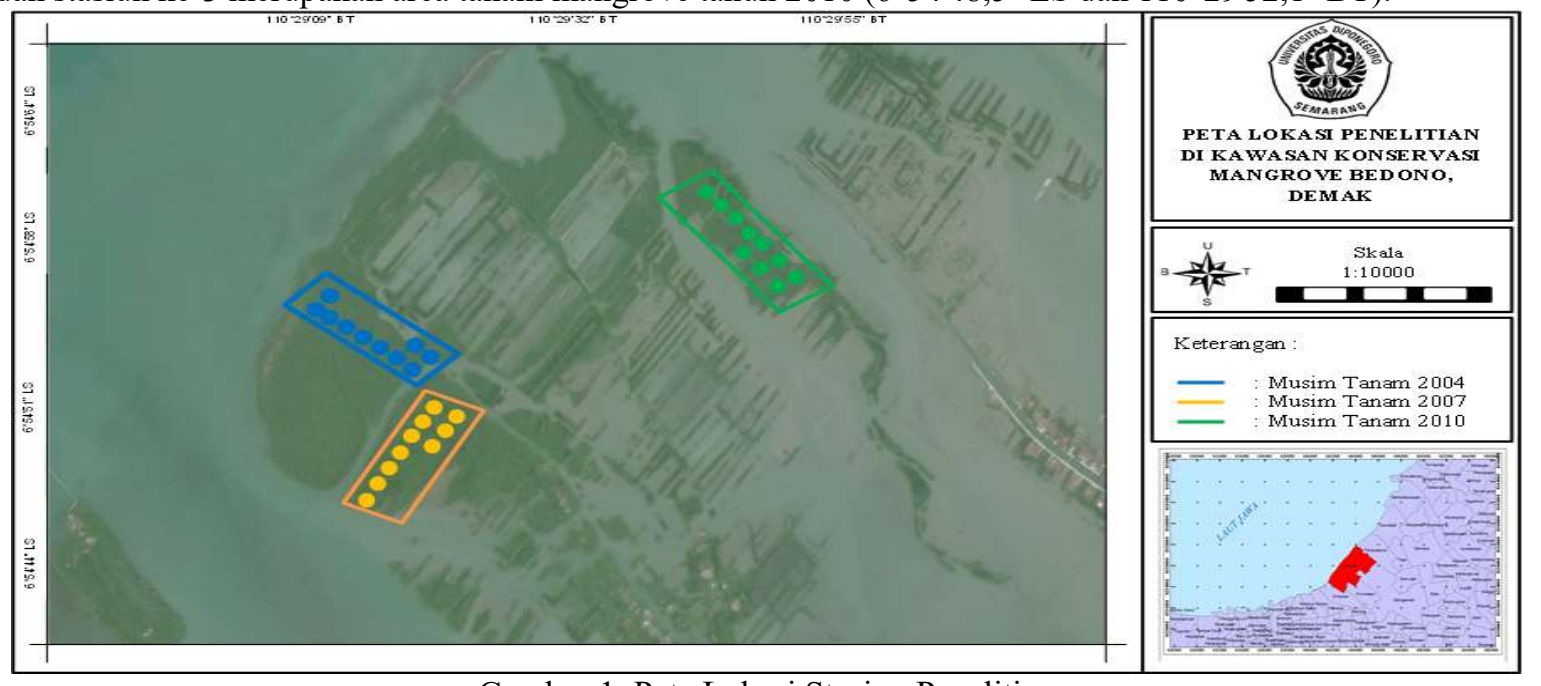

\section{B. Materi Penelitian}

Gambar 1. Peta Lokasi Stasiun Penelitian

Alat yang digunakan selama penelitian meliputi GPS untuk menentukan titik koordinat. Tali tambang dan rol 30 meter digunakan untuk membuat plot dan transek pada sampling lapangan. Pita meter digunakan untuk mengukur diameter batang (dbh). Hagameter digunakan untuk mengukur tinggi tanaman. Kamera digital digunakan untuk 
dokumentasi. Tally sheet pengukuran dan alat tulis untuk mencatat data. Bahan yang digunakan dalam penelitian adalah tegakan mangrove di kawasan konservasi mangrove, Bedono, Demak.

\section{Metode Penelitian}

Metode Sampling

Pengukuran kandungan karbon dilakukan dengan metode non-destruktif sampling dengan variabel yang diteliti yaitu biomassa dan kerapatan jenis mangrove. Penelitian dilakukan pada 3 stasiun penelitian yang ditentukan secara purposive sampling dengan memenuhi kriteria sebaran umur tanam tegakan mangrove yaitu umur tanam 2004, 2007 ,dan 2010. Total luas wilayah yang menjadi lokasi penelitian yaitu $30 \mathrm{Ha}$. Jumlah plot penelitian akan ditentukan dari luas wilayah penelitian dengan intensitas sampling (IS) sebanyak $1 \%$, sehingga dari perhitungan IS $1 \%$ diperoleh jumlah total plot penelitian yaitu 30 plot.

1. Kandungan Karbon Mangrove

Data yang digunakan dalam mengukur biomassa tegakan mangrove ialah diameter batang (dbh) dan tinggi pohon. Metode pengukuran dbh dan tinggi tegakan mangrove berdasarkan penelitian Murdiyarso et al. (2010); Kauffman dan Donato (2012); SNI 7724:2011, yaitu mengukur diameter batang tegakan setinggi dada $(137 \mathrm{~cm})$ menggunakan pita meter sedangkan tinggi tegakan mangrove diukur menggunakan alat Hagameter. Pengambilan sampel dilakukan menggunakan metode transek petakan kuadran atau petakan contoh (transect plot). Kriteria vegetasi yang ditemukan diklasifikasikan menurut Kartawinata et al., (1976).

Data diameter dan tinggi tegakan mangrove kemudian diolah menggunakan persamaan alometrik untuk mengetahi biomassa tegakan. Persamaan alometrik biomassa yang digunakan pada tegakan mangrove tersaji dalam Tabel 4.

Tabel 1. Persamaan Alometrik Biomassa

\begin{tabular}{cccc}
\hline Jenis & Persamaan Alometrik & Sumber Penalitian & Lokasi \\
\hline Avicennia marina & $\mathrm{Y}=0,1848(\mathrm{D})^{2,3524}$ & Dharmawan, 2010 & Purwakarta \\
Rhiophora mucronata & $\mathrm{R}^{2}=0,9839, \mathrm{D}_{\max }=35,2 \mathrm{~cm}$ & & Purwakarta \\
& $\mathrm{Y}=0,1466(\mathrm{D})^{2,3136}$ & Dharmawan dan Siregar, 2008 & \\
\hline
\end{tabular}

\section{Kerapatan Mangrove}

Kerapatan jenis adalah jumlah jenis individu per satuan luas. Pengambilan data kerapatan jenis mangrove dilakukan pada plot penelitian yang telah dibuat. Setiap plot penelitian, dilakukan identifikasi jenis tegakan mangrove, demikian pula dengan pencatatan jumlah individu tiap jenisnya tegakan mangrove. Data yang diperoleh, kemudian diolah berdasarkan persamaan Brower dan Zar (1989) sebagai berikut:

Keterangan:

$$
D i=\frac{n i}{A}
$$

$\mathrm{Di}=$ Kepadatan individu jenis ke-i (individu $\left./ \mathrm{m}^{2}\right)$

$\mathrm{ni}=$ Jumlah individu jenis ke-i yang diperoleh

$\mathrm{A}=$ Luas total area pengambilan contoh $\left(\mathrm{m}^{2}\right)$

\section{Metode Pengolahan Data}

\section{Kandungan Karbon}

Kandungan karbon pada tegakan mangrove dapat diketahui dengan mengkonversikan biomassa ke dalam karbon. Rumus yang digunakan untuk mengukur/memperkirakan kandungan karbon (Brown, 1997; Heriyanto dan Subiandono, 2012) adalah:

Dimana:

$$
\mathrm{C}=\mathrm{W} \times 50 \%
$$

$\mathrm{C} \quad=$ Kandungan karbon (ton/ha)

$\mathrm{W}=$ Biomassa (ton/ha)

2. Serapan Karbondioksida $\left(\mathrm{CO}_{2}\right)$

Data kandungan karbon digunakan untuk mengetahui serapan $\mathrm{CO}_{2}$. Kandungan karbon dikonversi ke dalam $\mathrm{CO}_{2}$ menggunakan persamaan (Dhamawan dan Siregar, 2008; Heriyanto dan Subiandono, 2012) berikut:

Dimana:

$\mathrm{CO} 2=$ Serapan Karbondioksida (ton/ha)

$\mathrm{Bm} . \mathrm{CO}_{2}=$ Berat molekul relatif senyawa $\mathrm{CO}_{2}(44)$

Ba. $\mathrm{C}=$ Berat relatif atom $\mathrm{C}(12)$

$\mathrm{C}=$ Kandungan Karbon (ton/ha)

$$
\mathrm{CO}_{2}=\frac{\mathrm{Bm} \cdot \mathrm{CO}_{2}}{\mathrm{Ba} \cdot \mathrm{C}} \times \mathrm{C}
$$




\section{Analisis Statistik}

1. Uji Akurasi

Salah satu tujuan pengukuran kandungan karbon hutan adalah memperoleh informasi tentang faktor emisi (emission factor), yaitu rata-rata cadangan karbon pada setiap tipe hutan dan tutupan lahan lainnya. Untuk memperoleh angka faktor emisi, maka hasil analisis data cadangan karbon per plot contoh harus dianalisis lebih lanjut, sehingga diperoleh rata-rata (mean), kesalahan baku rata-rata (standard error of mean), dan selang kepercayaan (confidence interval) serta kesalahan penarikan contoh (sampling error, SE) cadangan karbon pada setiap stratum. Nilai SE menyatakan besarnya persentase kesalahan pendugaan dari suatu penarikan contoh/sampling (Rusolono et al., 2015). Teknik pengambilan contoh yang digunakan adalah pengambilan contoh berlapis (stratified sampling) secara sistematik (stratified systematic sampling ) atau acak (simple random sampling), dengan toleransi kesalahan (sampling error) maksimal 20 \% (SNI 7724:2011). Perhitungan uji akurasi pada setiap stasiun dihitung dengan rumus Cochran (1977); Shiver dan Borders (1996); Sutaryo (2009).

2. Hubungan Kerapatan Mangrove dengan Kandungan Karbon

Analisis yang digunakan dalam menentukan hubungan kerapatan mangrove dengan kandungan karbon yaitu uji regresi - korelasi. Perhitungan uji statistik tersebut akan mendapatkan nilai r. Nilai r negatif (-) menunjukkan bahwa terdapat korelasi negatif atau berbanding terbalik antara kedua variabel, sedangkan untuk nilai $r$ positif $(+)$ menunjukkan bahwa terdapat korelasi positif atau berbanding lurus antara kedua variabel. Perhitungan uji regresikorelasi dilakukan menggunakan software Microsoft Excel (2010).

\section{HASIL DAN PEMBAHASAN}

Hasil

\section{A. Kerapatan Jenis Mangrove}

Kerapatan jenis merupakan jumlah tegakan jenis ke-i dalam suatu unit area. Spesies mangrove yang terdapat pada 3 stasiun penelitian terdiri dari 2 spesies, 2 famili, yaitu spesies Rhizophora mucronata dan Avicennia marina. Spesies ini merupakan spesies yang dominan pada area penelitian. Chafid et al. (2012) menyatakan, spesies mangrove yang banyak ditemukan di kawasan pesisir Desa Bedono, Kecamatan Sayung, Kabupaten Demak adalah Avicennia marina dan Rhizophora mucronata.

Data kerapatan mangrove pada masing jenis mangrove di setiap stasiun penelitian tersaji pada Tabel 2. Tabel 2. Kerapatan Jenis Mangrove Tiap Stasiun Penelitian

\begin{tabular}{|c|c|c|c|c|c|c|}
\hline No & Stasiun & $\begin{array}{c}\text { Fase } \\
\text { Pertumbuhan }\end{array}$ & Spesies & $\begin{array}{l}\text { Jumlah } \\
\text { Tegakan }\end{array}$ & $\begin{array}{c}\text { Kerapatan } \\
\text { (ind/Ha) }\end{array}$ & $\begin{array}{c}\text { Kriteria } \\
\text { Kerapatan }\end{array}$ \\
\hline \multirow[t]{6}{*}{1} & \multirow{5}{*}{$\begin{array}{l}\text { Area Tanam } \\
\text { Tahun } 2004\end{array}$} & Pancang & Rhizophora & 78 & 3120 & Padat \\
\hline & & $(5 \mathrm{~m} \times 5 \mathrm{~m})$ & mucronata & & & \\
\hline & & & Avicennia marina & 35 & 1400 & Sedang \\
\hline & & $\begin{array}{c}\text { Pohon } \\
(10 \mathrm{~m} \times 10 \mathrm{~m})\end{array}$ & $\begin{array}{c}\text { Rhizophora } \\
\text { mucronata }\end{array}$ & 59 & 590 & Jarang \\
\hline & & & Avicennia marina & 73 & 730 & Jarang \\
\hline & \multicolumn{2}{|c|}{ Rata-rata } & & & 1460 & Sedang \\
\hline \multirow[t]{5}{*}{2} & \multirow{4}{*}{$\begin{array}{l}\text { Area Tanam } \\
\text { Tahun } 2007\end{array}$} & Pancang & Rhizophora & 80 & 3200 & Padat \\
\hline & & $(5 \mathrm{mx} 5 \mathrm{~m})$ & $\begin{array}{c}\text { mucronata } \\
\text { Avicennia marina }\end{array}$ & 55 & 2200 & Padat \\
\hline & & $\begin{array}{c}\text { Pohon } \\
(10 \mathrm{mx} 10 \mathrm{~m})\end{array}$ & $\begin{array}{c}\text { Rhizophora } \\
\text { mucronata }\end{array}$ & 103 & 1030 & Sedang \\
\hline & & & Avicennia marina & 104 & 1040 & Sedang \\
\hline & \multicolumn{2}{|c|}{ Rata-rata } & & & 1868 & Padat \\
\hline \multirow[t]{5}{*}{3} & \multirow[t]{4}{*}{$\begin{array}{l}\text { Area Tanam } \\
\text { Tahun } 2010\end{array}$} & $\begin{array}{l}\text { Pancang } \\
(5 \mathrm{~m} \times 5 \mathrm{~m})\end{array}$ & $\begin{array}{c}\text { Rhizophora } \\
\text { mucronata }\end{array}$ & 119 & 4760 & Padat \\
\hline & & & Avicennia marina & 39 & 1560 & Padat \\
\hline & & $\begin{array}{c}\text { Pohon } \\
(10 \mathrm{mx} 10 \mathrm{~m})\end{array}$ & $\begin{array}{l}\text { Rhizophora } \\
\text { mucronata }\end{array}$ & 163 & 1630 & Padat \\
\hline & & & Avicennia marina & 56 & 560 & Jarang \\
\hline & \multicolumn{2}{|c|}{ Rata-rata } & & & 2128 & Padat \\
\hline
\end{tabular}

\section{B. Biomassa, Kandungan Karbon dan Serapan $\mathrm{CO}_{2}$}

Berdasarkan hasil penelitian, biomassa karbon mangrove di Kawasan Konservasi Mangrove Desa Bedono, Demak pada area tanam tahun 2004, 2007 dan 2010 tersaji pada Tabel 3 sebagai berikut: 
Tabel 3. Perhitungan Biomassa, Kandungan Karbon dan Serapan $\mathrm{CO}_{2}$

\begin{tabular}{lcccc}
\hline No & Stasiun & Biomassa (ton/ha) & Karbon (ton/ha) & Serapan CO2 (ton/ha) \\
\hline 1 & Tanam 2004 & 206,77 & 103,39 & 379,09 \\
2 & Tanam 2007 & 293,73 & 146,86 & 538,50 \\
3 & Tanam 2010 & 260,02 & 130,01 & 476,67 \\
\hline \multicolumn{2}{l}{ Rata-rata } & 253,50 & 126,75 & 464,75 \\
\hline
\end{tabular}

\section{Uji Akurasi Perhitungan Setiap Tutupan Area (Stratum)}

Uji akurasi bertujuan untuk mengetahui nilai aktual kandungan karbon tiap tutupan area (statum) yaitu kandungan karbon bernilai \pm (kurang/lebih) dan kesalahan penarikan contoh (sampling error, SE) kandungan karbon pada setiap stratum. Nilai SE juga mencerminkan tingkat ketelitian pendugaan cadangan karbon, dimana semakin kecil nilainya (biasa penelitian dikehendaki) maka pendugaan cadangan karbon semakin teliti (Rusolono et al., 2015). Hasil uji akurasi setiap tutupan area (stratum) tersaji pada tabel 4.

Tabel 4. Hasil Uji Akurasi setiap Tutupan Area (Stratum)

\begin{tabular}{ccccccc}
\hline No & Stasiun & $\begin{array}{c}\text { Luas } \\
\mathbf{( H a )}\end{array}$ & Cadangan Karbon (Ton/ha) & $\begin{array}{c}\text { Selang } \\
\text { Kesalahan } \\
\text { Kata-rata }\end{array}$ & $\begin{array}{c}\text { Kepercayaan } \\
\mathbf{9 5 \%}\end{array}$ & $\begin{array}{c}\text { Sampling error } \\
(\%)\end{array}$ \\
\hline 1 & Tanam 2004 & 10 & 103,38 & 10,231 & $103,38 \pm 20,46$ & 19,79 \\
2 & Tanam 2007 & 10 & 146,86 & 11,561 & $146,86 \pm 23,12$ & 15,74 \\
3 & Tanam 2010 & 10 & 130,01 & 8,029 & $130,01 \pm 16,06$ & 12,35 \\
\hline
\end{tabular}

Hasil perhitungan kesalahan penarikan contoh (sampling error) tutupan area tanam 2004, 2007, dan 2010 adalah 19,79 \%, 15,75\% dan 12,35\%. Hasil tersebut sesuai dengan SNI 7724:2011 tentang Pengukuran Lapangan Cadangan Karbon yaitu batas toleransi/nilai maksimal kesalahan penarikan contoh (sampling error) adalah 20\%, sehingga penelitian ini dapat dikategorikan teliti.

\section{Hubungan Kerapatan Mangrove terhadap Kandungan Karbon}

Persamaan regresi diperoleh dari hasil perhitungan kerapatan mangrove dengan kandungan karbon pada masingmasing plot setiap stasiun penelitian. Angka koefisien determinasi $\left(\mathrm{R}^{2}\right)$ menunjukkan keeratan hubungan antara kedua variabel yang diuji. Sebaran kandungan karbon di stasiun penelitian tersaji pada Gambar 2-4.

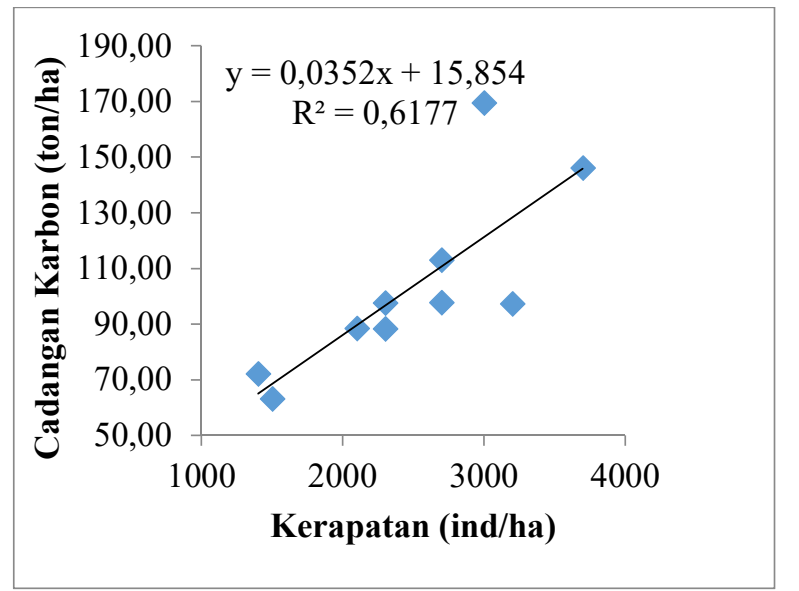

Gambar 2. Hubungan Kerapatan terhadap Kandungan Karbon di Area Tanam 2004

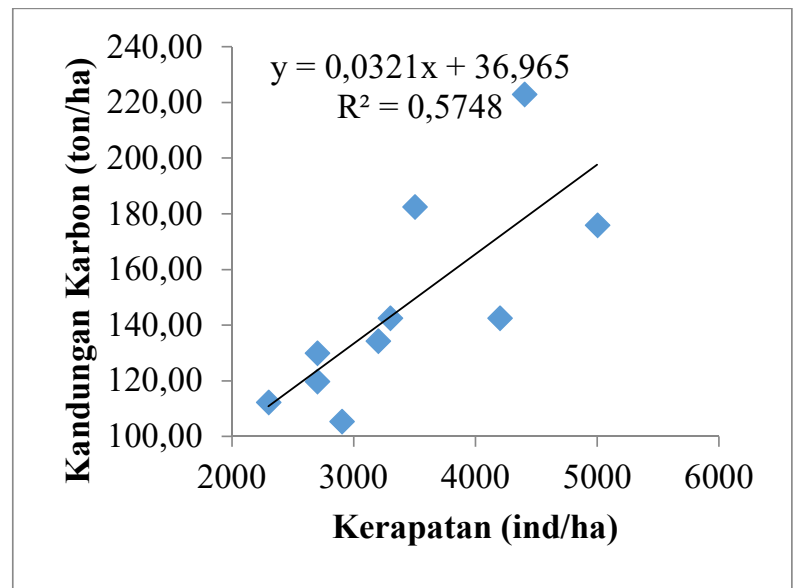

Gambar 3. Hubungan Kerapatan terhadap Kandungan Karbon di Area Tanam 2007 


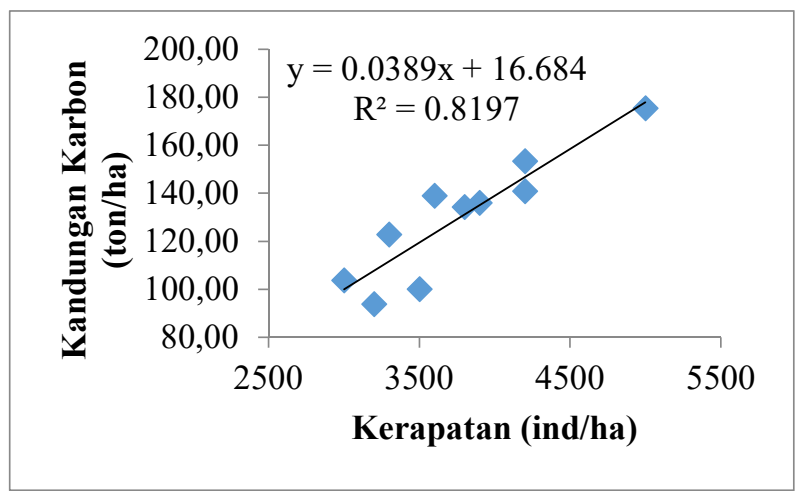

Gambar 4. Hubungan Kerapatan terhadap Kandungan Karbon di Area Tanam 2010 berikut:

Uji Korelasi dilakukan menggunakan Microsoft Excel (2010). Hasil perhitungan tersaji pada tabel 5 sebagai

Tabel 5. Hasil Uji Korelasi menggunakan Microsoft Excel (2010)

\begin{tabular}{ccc}
\hline Stasiun & Koefisien Korelasi (r) & Keeratan Hubungan \\
\hline Area tanam 2004 & 0,7859 & Korelasi Kuat \\
Area tanam 2007 & 0,7582 & Korelasi Kuat \\
Area tanam 2010 & 0,9054 & Korelasi Kuat Sekali \\
\hline
\end{tabular}

\section{Pembahasan}

Kawasan konservasi mangrove di Desa Bedono, Demak merupakan salah satu potensi yang dimiliki oleh Kabupaten Demak dalam mengurangi emisi $\mathrm{CO}_{2}$ di atmosfer. Desa Bedono memiliki mayoritas pencaharian sebagai nelayan, dimana proses penangkapan menggunakan perahu motor. Selain itu, Kecamatan Sayung merupakan kawasan industri di Demak, sehingga potensi polusi karbon di udara semakin tinggi. Oleh karena itu, peran ekosistem mangrove diperlukan salah satunya sebagai penyerap emisi karbon. Menurut Menurut Maiti dan Chowdhury (2013), mangrove berperan sebagai penyerap karbon dari atmosfir yang efektif dengan jumlah yang lebih tinggi (daripada jenis hutan nonbakau lainnya) yaitu \pm berjumlah 100 ton $\mathrm{CO}_{2}$ per hektar $(\mathrm{Ha})$.

\section{A. Kerapatan Jenis Mangrove}

Ekosistem mangrove sangat berpengaruh terhadap konsentrasi $\mathrm{CO}_{2}$ di atmosfer. Semakin banyak jumlah tegakan mangrove maka semakin baik dalam menyerap $\mathrm{CO}_{2}$. Perhitungan kerapatan mangrove dilakukan untuk mengetahui jumlah individu tegakan mangrove setiap luasannya. Berdasarkan hasil perhitungan, kerapatan mangrove tertinggi terdapat pada stasiun III (area tanam tahun 2010) yaitu 2128 individu/ha yang terkategori pada kerapatan padat, sedangkan kerapatan mangrove terendah terdapat pada stasiun I (area tanam tahun 2004) dengan kerapatan mangrove 1460 individu/ha yang terkategori kerapatan sedang. Menurut Kementerian Lingkungan Hidup (2004), kategori kerapatan sedang sampai padat menunjukkan kondisi hutan yang masih baik/asri.

Substrat pada lokasi tumbuh mangrove merupakan salah satu faktor yang menunjang keberhasilan pertumbuhan mangrove. Sistem perakaran mangrove merupakan bentuk adaptasi mangrove terhadap kondisi lingkungan. Spesies Avicennia marina memiliki sistem perakaran pneumatophore (akar nafas) yang muncul di permukaan tanah untuk aerasi, sedangkan Rhizophora mucronata memiliki perakaran tunjang yang berfungsi untuk menopang batang. Menurut Bengen (2004), adaptasi pohon mangrove terhadap keadaan tanah (lumpur) dan kekurangan oksigen dalam tanah adalah pembentukan morfologi sistem perakaran.

Kerapatan jenis mangrove pada area tanam 2004 paling rendah dari ketiga stasiun penelitian. Rendahnya kerapatan pada area tanam tahun 2004 dikarenakan pada lokasi tanam mangrove, memiliki jenis substrat cenderung berpasir dan hanya tergenangi air laut saat pasang. Kondisi substrat tersebut menyebabkan sistem perakaran mangrove sukar untuk menembus substrat, sehingga berdampak pada keberhasilan tumbuh mangrove. Hal ini sesuai dengan data lapangan yang ditemukan yaitu banyak kondisi mangrove yang roboh. Selain itu, hasil monitoring yang dilakukan Kelompok Mangrove Bahari menunjukkan persentase hidup mangrove pada penanaman tahun 2004 hanya $50 \%$ dari jumlah tegakan mangrove 13.750 bibit. Menurut Bangen (2001), spesies R. mucronata tumbuh di zona ke-2 setelah Avicennia dan Sonneratia dengan keadaan substrat lembek (lumpur).

\section{B. Biomassa, Kandungan Karbon dan Serapan $\mathrm{CO}_{2}$ pada Tegakan Mangrove}

Penelitian dilakukan dengan menghitung biomassa karbon mangrove berdasarkan kategori Intergovernmental Panel on Climate Change (IPCC) (2006), yaitu biomassa di atas permukaan. Perhitungan kandungan karbon mangrove diperlukan karena pentingnya ekosistem mangrove dalam siklus karbon pada wilayah pesisir. Kandungan karbon pada tanaman dapat diketahui dengan menghitung biomassa, oleh karena sebagian besar dari biomassa tanaman adalah kandungan karbon. Menurut Brown (1997) dan IPCC (2006) menyatakan bahwa, 45-50\% bahan kering (biomassa) tanaman terdiri dari kandungan karbon. 
Perhitungan biomassa dilakukan tanpa memanen tegakan mangrove, melainkan menggunakan persamaan alometrik tegakan mangrove. Biomassa pohon (dalam berat kering) dapat dihitung menggunakan "allometric equation" berdasarkan pada diameter batang setinggi dada (dbh) 1,3 m di atas permukaan tanah (Syam'ani et al., 2012; Murdiyarso et al., 2010; Kauffman dan Donato, 2012). Hasil penelitian menunjukkan bahwa dari jumlah 245 tegakan mangrove pada area tanam tahun 2004 memiliki biomassa 206,77 ton/ha, menyimpan karbon sebesar 103,39 ton/ha, dan menyerap $\mathrm{CO}_{2} 379,09$ ton/ha. Area tanam tahun 2007 terdapat 342 tegakan mangrove dengan biomassa 293,73 ton/ha, menyimpan karbon sebesar 146,86 ton/ha, dan menyerap $\mathrm{CO}_{2} 538,50$ ton/ha, sedangkan area tanam tahun 2010 terdapat 377 tegakan mangrove dengan biomassa 260,02 ton/ha, menyimpan karbon sebesar 130,01 ton/ha, dan menyerap $\mathrm{CO}_{2}$ 476,67 ton/ha.

Berdasarkan hasil penelitian, variabel umur mempengaruhi kemampuan tegakan mangrove dalam memproduksi biomassa. Umur mangrove yang lebih tua memiliki kemampuan memproduksi biomassa lebih banyak. Hal ini sesuai dengan hasil penelitian yaitu produksi biomassa cenderung naik dari umur tanam 2010 sampai dengan 2004. Semakin tua umur mangrove, tajuk pohon akan semakin luas, sehingga dapat memproduksi biomassa lebih banyak melalui proses fotosintesis (Rahayu et al., 2006). Namun berdasarkan hasil pengukuran, kandungan karbon tertinggi terdapat pada area tanam tahun 2007, dibandingkan dengan kandungan karbon pada umur mangrove tertua di area tanam tahun 2004. Hal ini menunjukkan, tegakan mangrove pada kondisi umur yang optimum akan menyimpan karbon lebih banyak, dengan diameter batang lebih besar. Hal ini sesuai data lapangan pada area tanam tahun 2007 memiliki rata-rata diameter batang terbesar yaitu $2,9 \mathrm{~cm}-31,5 \mathrm{~cm}$ dibandingkan area tanam 2004 yang memiliki rata-rata diameter batang $1,6 \mathrm{~cm}-27,7 \mathrm{~cm}$. Menurut Zamroni dan Rohyani (2008), umur mangrove yang melebihi titik umur optimum, maka batang mangrove akan semakin tua sehingga bagian dalamnya mulai keropos. Selain itu, tajuk pohon mulai menyempit. Hal ini menunjukkan, semakin tua umur mangrove maka laju kemampuan dalam menyerap $\mathrm{CO}_{2}$ akan semakin berkurang.

Total biomassa mangrove di kawasan konservasi mangrove Desa Bedono, Demak pada stasiun penelitian sebesar 253,50 ton/ha (setara dengan 126,75 ton $\mathrm{C}$ atau 464,75 ton $\mathrm{CO}_{2}$ ) dengan jumlah mangrove 964 tegakan. Biomassa di kawasan ini dikategorikan tinggi dibandingkan dengan biomassa mangrove di Taman Nasional Alas Purwo yaitu sebesar 217,22 ton/ha (setara 108,61 ton $\mathrm{C} /$ ha atau 398,60 ton $\mathrm{CO}_{2} /$ ha) berdasarkan penelitian Heriyanto dan Subiandono (2012). Hasil penelitian ini juga dikategorikan rendah dibandingkan dengan biomassa di KPH Purwakarta yaitu sebesar 364,9 ton/ha dan kandungan karbon sebesar 182,5 ton/ha atau 669,0 ton $\mathrm{CO}_{2} /$ ha pada penelitian Dharmawan dan Siregar, (2008). Menurut Kusmana (2002), kisaran umum biomassa yang dimiliki hutan mangrove antara 62,9-398,8 ton/ha, sehingga biomassa mangrove di kawasan konservasi mangrove Desa Bedono, Demak dapat dikategorikan sedang dengan kemampuan menyerap $\mathrm{CO}_{2}$ cukup baik.

\section{Hubungan Kerapatan Tegakan Mangrove dengan Kandungan Karbon}

Analisis regresi-korelasi dilakulan pada hasil perhitungan kerapatan mangrove dengan kandungan karbon pada setiap plot dalam masing-masing stasiun penelitian. Hasil perhitungan uji regresi, angka koefisien determinasi $\left(\mathrm{r}^{2}\right)$ pada setiap stasiun berturut-turut adalah 0,6177; 0,5748; dan 0,8197. Koefisien determinasi $\left(\mathrm{r}^{2}\right)$ tersebut termasuk dalam kategori baik, yaitu hubungan antar variabel memiliki keterkaitan yang erat. Menurut Setyorini et al. (2016), angka $\mathrm{r}^{2}$ menunjukkan tingkat kemampuan semua variabel bebas untuk mempengaruhi variable terikat, sedangkan sisanya ditentukan oleh variable lain di luar variabel bebas. Nilai R square dikatakan baik jika berada di atas 0,5.

Uji korelasi menunjukkan kategori korelasi kuat pada setiap stasiun penelitian. Angka koefisien korelasi (r) berturut-turut adalah 0,786; 0,758; dan 0,905. Keeratan hubungan antara kerapatan mangrove dan kandungan karbon dapat dijelaskan dengan angka koefisien korelasi (r). Angka koefisien korelasi (r) $=1$ dapat diartikan bahwa, hubungan kedua variabel yang diuji adalah sangat kuat dengan arah yang positif. Arah positif tersebut diartikan bahwa, semakin besar kerapatan mangrove maka kandungan karbon juga akan semakin besar. Menurut Misbahuddin dan Hasan (2013), angka $r$ berada diantara 0,7-0,9 menunjukkan korelasi kuat antar variabel yang diuji. Berdasarkan hasil uji dapat disimpulkan, adanya keterkaitan yang erat/kuat antara variabel kerapatan mangrove dengan kandungan karbon.

Kerapatan mangrove merupakan faktor yang mempengaruhi besarnya biomassa yang dihasilkan oleh mangrove di lokasi penelitian. Berdasarkan hasil uji regresi-korelasi, perubahan kerapatan mangrove akan berpengaruh secara signifikan pada ekosistem mangrove dalam menyimpan karbon dan menyerap $\mathrm{CO}_{2}$ dari atsmosfer. Menurut Satoo dan Madgwick (1982), kerapatan tegakan, komposisi dan struktur tegakan, serta kualitas tempat tumbuh mempengaruhi laju peningkatan biomassa karbon pohon. Dury et al. (2002) menambahkan, pengelolaan hutan yang baik seperti pengaturan penjarangan dan rotasi pohon juga mempengaruhi tingkat serapan karbon pada ekosistem.

\section{KESIMPULAN}

Berdasarkan hasil penelitian yang telah dilakukan dapat diambil kesimpulan sebagai berikut:

1. Kerapatan tegakan mangrove di kawasan konservasi mangrove Desa Bedono pada area tanam tahun 2004, 2007, dan 2010 masing- masing 1460 tegakan/ha, 1868 tegakan/ha, dan 2128 tegakan/ha;

2. Biomassa, kandungan karbon dan serapan $\mathrm{CO} 2$ pada masing-masing stasiun penelitian adalah sebagai berikut:

- Area tanam tahun 2004 memiliki biomassa 206,77 ton/ha, menyimpan karbon sebesar 103,39 ton/ha, dan menyerap $\mathrm{CO}_{2} 379,09$ ton/ha. 
- Area tanam tahun 2007 memiliki biomassa 293,73 ton/ha, menyimpan karbon sebesar 146,86 ton/ha, dan menyerap $\mathrm{CO}_{2} 538,50$ ton/ha, sedangkan

- Area tanam tahun 2010 memiliki biomassa 260,02 ton/ha, menyimpan karbon sebesar 130,01 ton/ha, dan menyerap $\mathrm{CO}_{2} 476,67$ ton/ha.

3. Hubungan antara kerapatan mangrove dan kandungan karbon menunjukkan adanya keterkaitan yang erat/kuat antara variabel kerapatan mangrove dengan kandungan karbon.

\section{UCAPAN TERIMA KASIH}

Penulis menyampaikan ucapan terima kasih kepada Dr. Ir. Pujiono Wahyu Purnomo, M.S. yang telah memberikan bimbingan, saran dan masukan dalam menyelesaikan penelitian, serta kepada semua pihak yang telah membantu dalam penyusunannya sampai selesai.

\section{DAFTAR PUSTAKA}

Azizah, M., E.v R. Ardli, dan E. Sudiana. 2013. Analisis Stok Karbon Hutan Mangrove pada Berbagai Tingkat Kerusakan di Segara Anakan Cilacap. Jurnal Sains Natural 3(2): 161-172

Bengen, D.G. 2001. Pedoman Teknis Pengenalan dan Pengelolaan Ekosistem Mangrove. Pusat Kajian Sumberdaya Pesisir dan Lautan. IPB, Bogor.

2004. Ekosistem dan Sumberdaya Alam Pesisir dan Laut Serta Prinsip Pengelolaannya. Pusat Kajian Sumberdaya Pesisir dan Lautan (PKSPL) IPB, Bogor.

Brower, J and J. Zar. 1989. General ecology, field and laboratory methods. Brown Company Publ. Dubugue. Iowa.3

Brown, S., 1997. Estimating Biomass and Biomass Change of Tropical Forests: a Primer. FAO FORESTRY PAPER 134, Rome: FAO - Food and Agriculture Organization of the United Nations.

Cochran. 1977. Sampling Techniques. John Wiley \& Sons, New York

Dharmawan, I. W. S., dan C. A. Siregar. 2008. Karbon Tanah dan Pendugaan Karbon Tegakan Avicennia marina (Forsk.) Vierh di Ciasem, Purwakarta. Jurnal Penelitian hutan dan Konservasi Alam 5(4): 317-328

Donato, D. C., J. B.Kauffman, D. Murdiyarso, S. Kurnianto, M. Stidham, and M. Kanninen. 2011. Mangroves among the most carbon-rich forests in the tropics. Nature Geoscience, DOI: 10.1038/NGEO1123

Dury S.J., P.J. Polglase, and T. Vercose. 2002. Greenhouse Resource Kit for Private Forest Growers. Commonwealth Department of Agriculture Fisheries and Forestry, Canberra, Australia, 4: 95.

Gilman, E. L., J. Ellison, N. C. Duke, and C. Field. 2008. Threats to Mangroves from Climate Change and Adaptation Options. Aquatic Botany, doi:10.1016/j.aquabot.2007.12.009

Heriyanto, N. M. dan E. Subiandono. 2012. Komposisi dan Struktur Tegakan, Biomasa, dan Potensi Kandungan Karbon Hutan Mangrove di Taman Nasional Alas Purwo. Jurnal Penelitian Hutan dan Konservasi Alam 9(1): 23-32

Intergovernmental Panel on Climate Change (IPCC). 2006. IPCC Guidelines for National Greenhouse Gas Inventories, Prepared by the National Greenhouse Gas Inventories Programme, eds Eggleston HS, Buendia L, Miwa K et al. IGES, Hayama

Kartawinata, K., S. Soenarko., IGM. Tantra dan T. Samingan. 1976. Pedoman Inventarisasi Flora dan Ekosistem. Direktorat Perlindungan dan Pengawetan Alam, Bogor.

Kauffman, J.B. and D.C. Donato. 2012 Protocols for The Measurement, Monitoring and Reporting of Structure, Biomass and Carbon Stocks in Mangrove Forests. Working Paper 86. CIFOR, Bogor, $40 \mathrm{hlm}$.

Kusmana, C. 2002. Pengelolaan Ekosistem Mangrove Secara Berkelanjutan dan Berbasis Masyarakat. Lokakarya Nasional Pengelolaan Ekosisitem Mangrove di Jakarta, 6-7 Agustus 2002

Maiti, S. K., and A. Chowdhury. 2013. Effects of Anthropogenic Pollution on Mangrove Biodiversity: A Review. Journal of Environmental Protection, 4: 1428-1434

Misbahuddin dan I. Hasan. 2013. Analisis Data Penelitian dengan Statistika. Bumi Aksara. Jarakta, 346 hlm.

Murdiyarso, D., D. C. Donato, J. B. Kauffman, S. Kurnianto, M. Stidham, dan M. Kanninen. 2010. Carbon Storage in Mangrove and Peatland Ecosystems: A Preliminary Account from Plots in Indonesia. CIFOR. Bogor, $35 \mathrm{hlm}$.

Rahayu, S., B. Lusiana, dan M. V. Noordwijk. 2006. Pendugaan Cadangan Karbon di Atas Permukaan Tanah pada Berbagai Sistem Penggunaan Lahan di Kabupaten Nunukan, Kalimantan Timur. ICRAF. Bogor, $87 \mathrm{hlm}$

Rusolono, T., T. Tiryana, dan J. Purwanto. 2015. Panduan Survei Cadangan Karbon dan Keanekaragaman Hayati di Sumatera Selatan. German International Cooperation (GIZ), Dinas Kehutanan, Palembang. $73 \mathrm{hlm}$.

Sato, T., and H.A. Madgwick. 1982. Forest Biomass. Martinus Nil hoff / Dr W. Junk Publishers. London, $152 \mathrm{hlm}$

Sedjarawan, W., Akhbar, dan I. Arianingsih . 2014. Biomassa dan Karbon Pohon di Atas Permukaan Tanah di Tepi Jalan Taman Nasional Lore Lindu (Studi Kasus Desa Sedoa Kecamatan Lore Utara Kabupaten Poso). Jurnal Warta Rimba 2(1) : 105-111

Shiver B.D., and B.E. Borders. 1996. Sampling Techniques for Forest Resource Inventory. John Willey \& Sons, New York

Standart Nasional Indonesia (SNI). 2011. Pengukuran dan Penghitungan Cadangan Karbon - Pengukuran Lapangan untuk Penaksiran Cadangan Karbon Hutan. SNI 7724:2011. $16 \mathrm{hlm}$

Zamroni, Y., dan I. C. Rohyani. 2008. Produksi Serasah Hutan Mangrove di Perairan Pantai Teluk Sepi, Lombok Barat. Jurnal Biodiversitas 9 (4): 284-287 